ISSN 0258-7122

Bangladesh J. Agril. Res. 36(3) : 449-454, September 2011

\title{
FIELD PERFORMANCE AND ECONOMIC ANALYSIS OF SOME COMMONLY USED INSECTICIDES AGAINST TEA MOSQUITO BUG, Helopeltis theivora W.
}

\author{
M. AHMED ${ }^{1}$, S. K. PAUL ${ }^{2}$ AND M. S. A. MAMUN ${ }^{3}$
}

\begin{abstract}
A study was undertaken to evaluate the field performance and economic analysis of some commonly used insecticides against Tea mosquito bug, Helopeltis theivora Waterhouse at Bangladesh Tea Research Institute (BTRI), Srimangal, Moulvibazar. Six different insecticides-Thiodan 35EC (Endosulfan), Ripcord 10EC (Cypermethrin), Decis 2.5EC (Deltamethrin), Dimethion 40EC (Dimethoate), Metasystox 25EC (Oxydemeton), and Malathion 57EC (Malathion) were applied in the plots as recommended dose of BTRI. The shoot infestation reduction as well as yield response of all the insecticides treated plots were superior over the control but there was no significant difference among the insecticidal treatments. Better field performance against Helopeltis was found in Malathion 57 EC treated plots in respect to shoot infestation reduction over control (87.09\%). Per hectare yield $(1910.33 \mathrm{~kg})$ as well as per hectare net return (Tk. 300927.80) were also higher in Malathion 57EC treated plots. The highest marginal rate of return (2580.57\%) was obtained by spraying Metasystox 25EC over control followed by Ripcord IOEC (1710.87\%) and other insecticides. The most economically acceptable insecticide against tea mosquito bug was Metasystox.
\end{abstract}

Keywords: Field performance, economic analysis, insecticides, tea, Helopeltis theivora.

\section{Introduction}

Tea is a major cash crop as well as a vital export item in Bangladesh, accounting for $0.22 \%$ GDP (Ahmed, 2005). Like other crops, since the dawn of tea culture, wide arrays of pests have been associating with tea plantations. An extensive monoculture of a perennial crop like tea over contiguous area in an apparently isolated ecological zone has formed virtually a stable ecosystem or hiding environment for widely divergent endemic pests. In Bangladesh tea, the pestspectrum comprises 25 insects, 4 mites, and 10 species of nematodes (Sana, 1998). Only a few of them have become major pests, while most of them are minor and localized and cause occasional damage. Tea mosquito bug, Helopeltis theivora W. (Hemiptera: Miridae) is one of the major pests of tea in Bangladesh causing serious damage to tea plantation in respect to both quantity and quality of tea (Ahmed et al., 1993). This bug bears no relation to mosquito and the name 'Tea mosquito bug' is simply a misnomer (Ahmed, 2005). This is also known as

${ }^{1}$ Chief Scientific Officer, ${ }^{2 \& 3}$ Scientific Officer, Entomology Division, Bangladesh Tea Research Institute (BTRC), Srimangal-3210, Moulvibazar, Bangladesh. 
'Helopeltis' to the planters. Ali (1990) and Ahmed (1991) reported that $15 \%$ of tea crop is lost annually by Helopeltis which sometimes may go upto $100 \%$ crop loss. Two types of damage occur by tea mosquito bug, such as direct loss of pluckable leaf and shoots and acute debilitation of the bushes leading to die-back which delay flushing with resultant poor yields (Rao, 1970).

As no other alternate effective control measure against tea mosquito bug is available, chemical insecticides have remained as the most powerful tools for controlling this pest in Bangladesh. The chemical method of pest control involves costly inputs like pesticides, fuel, labours, and spraying equipments. The overall cost of production of tea in Bangladesh is high and costs are escalating day by day due to increasing cost of pesticides and spraying equipment (Ahmed et al., 1998). It is very important to use those inputs effectively, economically, and judiciously at right time and in a proper way in order to minimize production costs and maximize benefits for a particular area (Muraleedharan, 1991). The present study was undertaken to evaluate the performance of some commonly used insecticides against tea mosquito bug and also to determine the most economically viable insecticide for controlling this pest.

\section{Materials and Method}

The study was carned out in the main farm of Bangladesh Tea Research Institute (BTR1), Srimangal, Moulvibazar during the cropping period from April to November 2009. Seven treatments in a Randomized Completely Block Design (RCBD) were in seven plots each of $10 \mathrm{~m} \times 5 \mathrm{~m}$ having 50 bushes per plot. Each treatment was replicated three times. Six treatments were the six insecticides with a recommended dose along with a control without insecticide were used (Table 1). The insecticides were sprayed with CP 15 Knapsack sprayer mixing with 500 l/ha of water.

The insecticides were applied six times as foliar spray for the control of Helopeltis during the cropping season. The first spray was done on the $4^{\text {th }}$ of April, $3^{\text {rd }}$ spray on $4^{\text {th }}$ July, and $15^{\text {th }}$ spray on $4^{\text {th }}$ of October 2009 followed by a spray at 21 days after each of these dates. Other agronomic practices i.e., plucking round, pruning frequency, weeding were done by the farm management at 7 days, 4 years, 90 days interval, respectively, and mulching was done during dry period. An acute infestation was noticed at initial stage of study. It is recommended that if $10 \%$ pluckable shoots are infested only then insecticides should be applied (Ahmed et al., 1998). Therefore, the first application of the insecticides was made at this time. Pretreatment data was taken before spraying of chemicals. Post-treatment data, such as \% shoot infestation as well as total shoot weight were recorded at weekly interval from each plot. Yield of the respective treatment plots were converted into yield per hectare. The per cent shoot infestation and shoot infestation reduction over control for each treatment 
were calculated. Only variable costs (costs of insecticides per hectare) of different insecticides were considered for these treatments and the rest of the costs were considered to be constant. Variable costs are those costs which vary proportionately with saleable produce. The economic analysis by using partial budgeting technique (Perri et al., 1988) was carried out to find out the economically viable insecticide against tea mosquito bug. The data were statistically analyzed by Randomized Complete Block Design (RCBD) using MSTAT statistical software in a microcomputer. The means were separated by Duncan’s Multiple Range Test (DMRT).

\section{Results and Discussion}

The comparative effectiveness of various treatments on the shoot infestation and yield of tea crop are presented in Table 1 . All the treatments significantly reduced the per cent shoot infestation as well as increased yield as compared to untreated control. The results revealed that significantly $(\mathrm{p}<0.05)$ the highest shoot infestation (34.16\%) was obtained in the untreated control. The treated plots should identical shoot infestation managing from 4.41 to $6.18 \%$ with 81.91 87.09\% reduction over control (Table 1). Islam et al. (1999) observed the minimum acceptable level of shoot infestation reduction over control was $80 \%$. The insecticidal treatments of the present study provided shoot infestation reduction over control within the acceptable limit.

Table 1. Percentages of tea shoot infestation by tea mosquito bug and yield of tea crop (April to November 2009).

\begin{tabular}{l|l|l|l|l|l}
\hline \multicolumn{1}{c|}{ Insecticides } & $\begin{array}{c}\text { Dose } \\
\text { used } \\
\text { (t/ha) }\end{array}$ & $\begin{array}{c}\text { Mean shoot } \\
\text { infestation } \\
(\%)\end{array}$ & $\begin{array}{c}\text { Shoot } \\
\text { infestation } \\
\text { reduction over } \\
\text { control (\%) }\end{array}$ & $\begin{array}{c}\text { Mean yield } \\
(\mathrm{kg} / \mathrm{ha})\end{array}$ & $\begin{array}{c}\text { Increase of } \\
\text { yield over } \\
\text { control (\%) }\end{array}$ \\
\hline Thiodan 35EC & 1.5 & $5.89 \pm 0.24 \mathrm{a}$ & 82.76 & $1816.21 \mathrm{a}$ & 19.38 \\
Ripcord 10EC & 0.5 & $6.18 \pm 0.56 \mathrm{a}$ & 81.91 & $1808.26 \mathrm{a}$ & 18.86 \\
Decis 2.5EC & 0.5 & $5.96 \pm 0.60 \mathrm{a}$ & 82.55 & $1812.61 \mathrm{a}$ & 19.14 \\
Dimethion 40EC & 2.25 & $5.12 \pm 0.68 \mathrm{a}$ & 85.01 & $1856.15 \mathrm{a}$ & 22.01 \\
Metasystox 25EC & 0.5 & $4.52 \pm 0.76 \mathrm{a}$ & 86.77 & $1895.54 \mathrm{a}$ & 24.60 \\
Malathion 57EC & 2.25 & $4.41 \pm 0.15 \mathrm{a}$ & 87.09 & $1910.33 \mathrm{a}$ & 25.57 \\
Untreated Control & - & $34.16 \pm 1.82 \mathrm{~b}$ & - & $1521.35 \mathrm{~b}$ & - \\
\hline
\end{tabular}

Means of 3 replications in a column having the same letter did not differ significantly by DMRT ( $>0.05)$.

The yield of tea crop also increased significantly in all the treated plots in comparison with the untreated plots. The identical yield from 1808.26 to 1910.33 
$\mathrm{kg} / \mathrm{ha}$ produced in the insecticides treated plots. The percent increase of yield due to various treatments against tea mosquito bug over untreated control ranged from $18.86 \%$ to $25.57 \%$. The present findings were similar to that of Mahapatro, G. K. (2007).

The parameters of partial budgeting technique i.e., average yield, variable cost, gross return, and net return of different insecticides were calculated. The highest net return of Tk. 300927.80/ha was obtained in Malathion 57EC treated plots followed by Metasystox 25EC (300136.40 Tk./ha) and rest of the insecticides, such as Dimethion 40EC, Decis 2.5EC, Ripcord 10EC, and Thiodan 35EC had net return within the range lower than Malathion and Metasystox treated plots (Table 2).

According to Perrin et al., 1988, a treatment is said to be 'dominated' when there is at least one option that offers a greater net return at an equal or lesser cost and a treatment is 'undominated' when no other options exist offering a greater net return at an equal or lesser cost. The treatments of Thiodan 35EC and Dimethion 40EC with variable cost of Tk. 5040 and 7763, respectively, were cost dominated due to its higher cost compared to lower net return. So these two treatments were eliminated for further analysis.

Table 2. Partial budget of different insecticidal treatments applied for controlling tea mosquito bug in mature tea.

\begin{tabular}{l|l|l|l|c|c}
\hline \multicolumn{1}{c}{ Insecticides } & $\begin{array}{c}\text { Dose used } \\
(\mathrm{t} / \mathrm{ha})\end{array}$ & $\begin{array}{c}\text { Average } \\
\text { yield } \\
(\mathrm{kg} / \mathrm{ha})\end{array}$ & $\begin{array}{c}\text { Variable } \\
\text { cost } \\
(\mathrm{Tk} . / \mathrm{ha})\end{array}$ & $\begin{array}{c}\text { Gross } \\
\text { return } \\
(\mathrm{Tk} . / \mathrm{ha})\end{array}$ & $\begin{array}{c}\text { Net return } \\
\text { (Tk./ha) }\end{array}$ \\
\hline Thiodan 35EC & 1.50 & 1816.21 & 5040 & 290593.60 & 285553.60 \\
Ripcord 10EC & 0.50 & 1808.26 & 2535 & 289321.60 & 286786.60 \\
Decis 2.5EC & 0.50 & 1812.61 & 2655 & 290017.60 & 287362.60 \\
Dimethion 40EC & 2.25 & 1856.15 & 7763 & 296984.00 & 289221.00 \\
Metasystox 25EC & 0.50 & 1895.54 & 3150 & 303286.40 & 300136.40 \\
Malathion 57EC & 2.25 & 1910.33 & 4725 & 305652.80 & 300927.80 \\
Untreated Control & - & 1521.35 & - & 243416.00 & 243416.00 \\
\hline
\end{tabular}

Cost of insecticIdes: Thiodan 35EC (Tk. 560/lit, Ripcord 10EC @ Tk. 845/lit, Decis 2.5EC Tk. 885/lit, Dimethion 40EC ( Tk. 575/lit, Metasystox 25EC @ Tk. 1050/lit, and Malathion 57EC (Tk. 350/lit)

Auction price of made tea in 2009 @ 160 Tk/kg

${ }^{1}$ Gross return: yield x price of a particular product

${ }^{2}$ Net return: gross return-total variable cost

The performances of cost-undominated treatments have been shown through marginal analysis in Table 3. The purpose of marginal analysis was to reveal how 
the net return from investment increased as the amount of investment increased (Perrin et al., 1988). It was observed that Metasystox 25EC showed the highest marginal rate of return (2580.57\%) followed by Ripcord 10EC (1710. 87\%), Decis 2.5EC (480.00\%) and Malathion 57EC (50.25\%) (Table 3). It indicated that if the planters would spend an additional one hundred taka more by applying Metasystox 25EC, they could get an extra income of Tk. 2580.57 over the control.

Table 3. Marginal analysis of different insecticidal treatments applied for controlling tea mosquito bug in mature tea.

\begin{tabular}{|c|c|c|c|c|c|c|}
\hline Insecticides & $\begin{array}{c}\text { Dose } \\
\text { used } \\
(1 / \mathrm{ha})\end{array}$ & $\begin{array}{c}\text { Net return } \\
\text { (Tk./ha) }\end{array}$ & $\begin{array}{c}\text { Variable } \\
\text { cost } \\
\text { (Tk./ha) }\end{array}$ & $\begin{array}{l}\text { Marginal } \\
\text { net return }{ }^{1} \\
\text { (Tk./ha) } \\
\text { (a) }\end{array}$ & $\begin{array}{c}\text { Marginal } \\
\text { variable } \\
\text { cost }^{2} \\
\text { (Tk/ha) } \\
\text { (b) }\end{array}$ & $\begin{array}{c}\text { Marginal } \\
\text { rate of } \\
\text { return (\%) } \\
(\mathrm{a} / \mathrm{b} \text { x 100) }\end{array}$ \\
\hline Malathion 57EC & 2.25 & 300927.80 & 4725 & 791.40 & 1575 & 50.25 \\
\hline Metasystox 25EC & 0.50 & 300136.40 & 3150 & 12773.80 & 495 & 2580.57 \\
\hline Decis 2.5EC & 0.50 & 287362.60 & 2655 & 576.00 & 120 & 480.00 \\
\hline Ripcord 10EC & 0.50 & 286786.60 & 2535 & 43370.60 & 2535 & 1710.87 \\
\hline Untreated Control & - & 243416.00 & - & - & - & - \\
\hline
\end{tabular}

${ }^{1}$ Marginal Net return: The increase in revenue of a farm caused by increasing one extra unit of inputs.

${ }^{2}$ Marginal Variable Cost: The increase in the variable cost of farm caused by increased output by one extra unit.

\section{Conclusion}

Shoot infestation reduction as well as tea yield were significantly higher with no significant difference among the plots treated with other insecticides than that of untreated control. From the economic point of view, Metasystox 25EC showed the highest marginal rate of return compared to all other insecticides. So, Metasystox 25EC@0.50 1/ha is the most economically acceptable insecticide for controlling tea mosquito bug.

\section{References}

Ahmed. M. 1990. Decision analysis of tea pests management in Bangladesh. M.Sc. Thesis, Imperial College of Science, Technology and Medicine, London University, UK, 110.

Ahmed, M. 2005. Tea Pest Management. Evergreen Printing and Packaging, Dhaka, pp.1-29. 
Ahmed, M., J.K. Saha and S.U. Gazi. 1998. Economics of Spraying Endosulfan and Synthetic Pyrethroids against Tea Mosquito Bug (Helopeltis theivora Waterh.). Two and $a$ Bud. 45(2): 11-14.

Ahmed, M., M. Huq, M. I. Haq and M. Ali. 1993. Influence of shade on the incidence of pests in tea plantation in Bangladesh. Proc. International Symposium on Tea Science \& Human Health, Calcutta, India: 329-329.

Ali, MA. 1991. Pest spectrum of Bangladesh Tea and its management. Tea Research Global Perspective. Proc. International Conference on $R \& D$ in Tea, Calcutta, India: 112-1 17.

Islam, M. N., N. K. Kumar and M. A. Karim. 1999. Efficacy of different insecticides for the control of okra shoot and fruit borer, Earias vittella F. Annual Report 1998-99. BARI, Joydebpur, Gazipur, Bangladesh: 33-34.

Mahapatro, G. K. 2007. Evaluation of insecticidal sprays for control of tea mosquito bug Helopeltis antonhi and other insect-pests in cashew. Paper presented in 19th Kerala Science Congress, 29-31 January 2007, Kannur, Kerala.

Muraleedharan, N. 1991. Pest Management in Tea. The United Planters' Association of South India (UPASI) Tea Research Institute, Valparai, Coimbatore, Tamil Nadu, pp.1-19.

Perrin, R.K., D. L. Winkelman, E.R. Moscardi and J.R. Anderson. 1988. From Agronomic Data to Farmer Recommendations: An Economic Training Manual. International Maize and Wheat Improvement Center (CIMMYT), Mexico.

Rao, G.N. 1970. Helopeltis: A breakthrough in its control. UPASI Tea Sci. Dept. Bull. No. 28: 2 1-28, India.

Sana, D. L. 1989. Tea Science. Ashrafia Boi Ghar, 36, Bangla Bazar, Dhaka, Bangladesh, pp. 106-200. 